\title{
Constraining functional hypotheses: controls on the morphology of the concavo-convex brachiopod Rafinesquina
}

\author{
LINDSEY R. LEIGHTON
}

\section{LETHAIA}

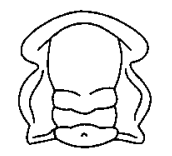

Leighton, L.R. 199812 15: Constraining functional hypotheses: controls on the morphology of the concavo-convex brachiopod Rafinesquina. Lethaia, Vol. 31, pp. 293-307. Oslo. ISSN 0024-1164.

The concavo-convex shape of strophomenoid brachiopods has been inferred to be adaptive to a free-lying state. Such functional hypotheses should be constrained by identifying the factors controlling morphology. A typical strophomenoid, Rafinesquina alternata, is used here to study morphological influences. Specimens of $R$. alternata were collected from ten localities in Indiana, USA. Beds are Upper Ordovician (Richmondian) mudstones and limestones of the Dillsboro and Whitewater Formations. Length and hingeline width of the pedicle valve were measured, and elongation (length divided by width) calculated for each specimen. Specimens were qualitatively identified as geniculate or arcuate. Regression analyses using stratigraphy (time), mudstone percentage (substrate), grainstone percentage (disturbance), ratio of Strophomena planumbona to $R$. alternata (competition), and length (ontogeny) as independent variables, were performed to determine the factors influencing morphology. Elongation was most strongly influenced by grainstone percentage and the $S$. planumbona ratio. Populations of $R$. alternata from grainstone-rich intervals are less elongate than other samples. The lateral margins of transverse $R$. alternata may have functioned as sediment traps during periods of high turbidity. Alternatively, variation in elongation may be a character displacement due to interspecific competition with the related S. planumbona, which is inferred to have had a similar life mode. $R$. alternata specimens found in beds dominated by $S$. planumbona are more elongate than $R$. alternata from beds in which $S$. planumbona is rare or absent. Geniculation was influenced by stratigraphic position, suggesting an evolutionary trend, and by limestone percentage. Geniculate individuals are most common in muddier intervals, supporting the hypothesis that geniculation enabled $R$. alternata to employ an 'iceberg' strategy, 'floating' convex down on the soft muds. The habitat distribution of $R$. alternata is inconsistent with the hypothesis that concavo-convex brachiopods lived convex-valve-up, as suggested by Lescinsky (1995). Both elongation and geniculation may be examples of phenotypic plasticity. $\square$ Functional morphology, concavo-convex brachiopods, RAFINESQUINA, Ordovician, Indiana.

Lindsey R. Leighton [lleighto@umich.edu], Museum of Paleontology, University of Michigan, Ann Arbor, MI 48109, USA; 7th October, 1997; revised 1st October, 1998.
Functional morphology provides insight into the autecology of organisms. However, research that demonstrates plausibility of a functional interpretation does not prove definitively that a given interpretation is correct, merely that the interpretation is feasible. To constrain functional hypotheses, the factors influencing the morphology of an organism should be identified. Moreover, as suggested by Savarese (1995a, b), the interpretation should be consistent with the organism's environmental occurrence. The intent of this study is to identify the factors influencing morphological change in a common Upper Ordovician strophomenoid brachiopod, Rafinesquina alternata (Conrad, 1838), in order to clarify further the autecology of the species and possibly that of higher taxonomic ranks.
Many brachiopods of the superfamily Strophomenoidea, including R. alternata, lacked a functional pedicle as adults and so lived unattached to the substrate. Free-lying brachiopods may have been subject to greater risk than attached brachiopods from transport by currents or from burial in soft sediments. Many workers (Lamont 1934; Rudwick 1970; Richards 1972; Alexander 1972, 1975, 1989; Alexander \& Daley 1994; Bretsky \& Bretsky 1975; Savarese 1994) have interpreted the external morphology of these brachiopods as an adaptive response to the free-lying condition. Rather than possessing the biconvex shape common to most other brachiopods, strophomenoids have one convex and one concave valve. In the case of $R$. alternata, the pedicle valve is convex and the brachial valve concave. In addition to stro- 

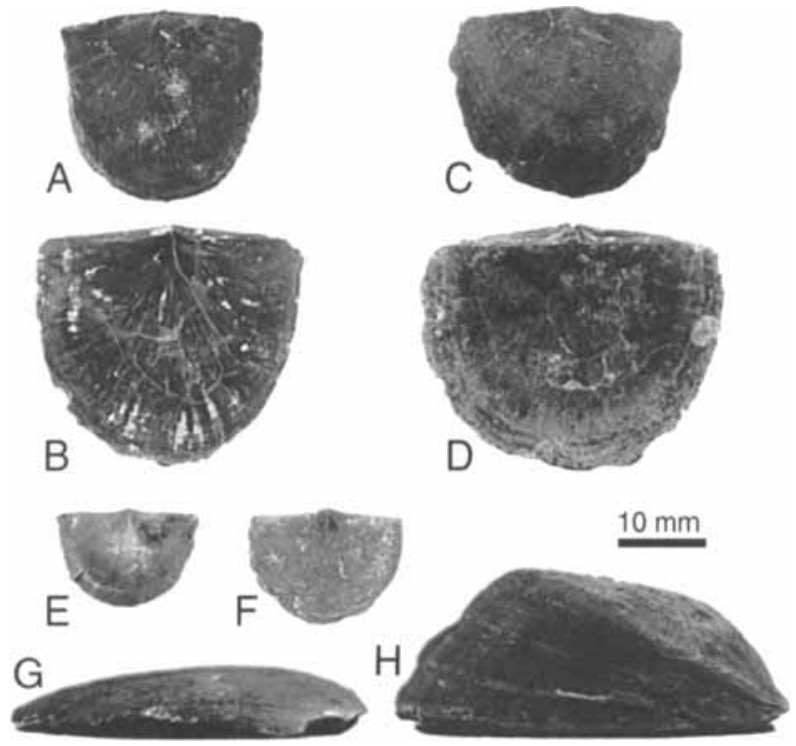

Fig. 1. Morphological variation in Rafinesquina alternata (A-D, G-H), with Strophomena plammbona $(E-F)$ for comparison. $\mathrm{A} A-\mathrm{B}$. Transverse morphotype, plan view. $\square C-D$. Equidimensional morphotype, plan view. $\square E-F$. S. planumbona, plan view. $\square \mathrm{G}-\mathrm{H}$. Arcuate $(\mathrm{G})$ and geniculate $(\mathrm{H})$ morphotypes, profile views, anterior to the left. Both specimens are oriented convex-valve (pedicle valve) up. $A, C, E, G$, and $\mathrm{H}$ are oriented convex-valve up (pedicle valve for Rafinesquina, brachial valve for Strophomena.

phomenoids, other strophomenides, such as plectambonitoids, chonetidines, and productides, as well as some pteriomorph pelecypods, commonly have a concavoconvex shape.

The goal of many of the aforementioned studies has been to determine the functional benefits of the concavoconvex shape to a free-lying brachiopod. Rafinesquina alternata is ideal for functional studies of the concavoconvex morphology because the species displays a broad range of morphological variation. This range of variation encompasses the morphologies of many other strophomenoids. Variation of the external geometry of $R$. alternata is manifested primarily in three ways:

1 Plan-view morphology of $R$. alternata may be strongly transverse (wider than long), equidimensional, or rarely elongate (longer than wide; Fig. IA).

2 Plan-view morphology may be alate (sensu Alexander 1975, hinge line wider than width at midpoint) or ovate (hinge line approximately equal in width to midwidth). The two aspects of plan-view morphology may not be independent.

3 Curvature of the sagittal profile may change abruptly, producing a sharp bend, termed a geniculation, in the profile. If the brachiopod lives long enough, this change in the direction of shell accretion results in greater relief of the sagittal profile. In contrast, other individuals within the species may have a flatter, more smoothly arcuate profile (Fig. 1B).
Functional inferences regarding geniculation and planview morphology are significant in reconstructing the ecology of R. alternata. Lamont (1934) and, subsequently, Richards (1972) inferred that concavo-convex brachiopods were semi-infaunal organisms, living convex-valvedown. Richards believed that geniculation was a direct response to sedimentation, enabling the brachiopod to keep its commissure above the sediment, and that these brachiopods were well adapted to soft, muddy substrates. More recently, Lescinsky (1995) suggested that concavoconvex strophomenoid brachiopods lived with their convex valve up. All of these studies used epibiont distribution on brachiopods to infer orientation and life mode. These results may be strongly influenced by the taphonomic interpretation, because post-mortem encrustation of the host obviously is not a reliable indication of life orientation. These epibiont distribution studies may demonstrate functional plausibility but are not conclusive.

Biomechanical studies (Leighton \& Savarese 1995, 1996) suggest that the convex-up position probably is detrimental to the brachiopod on both soft and hard substrates, particularly if the individual is geniculate. On liquid-rich muds, the commissure of a convex-up brachiopod will sink below the substrate, rendering feeding impossible (Leighton \& Savarese 1995, 1996). On hard substrates, the convex profile of a geniculate, convex-up brachiopod acts as a bluff body to currents, generating sediment scour upstream of the brachiopod, and burying the downstream margin. Unless the individual always was oriented with the commissure facing exactly upstream (assuming the highly unlikely possibility that the current never changed direction), the brachiopod would have to filter large quantities of sediment when feeding (Leighton \& Savarese 1995, 1996). Although problematic, this life strategy is plausible; a convex-up brachiopod living on soft substrates is not. If Lescinsky (1995) is correct, then geniculate brachiopods would favor a hard substrate.

Alexander $(1972,1975)$ was the first to quantify the shape of $R$. alternata, and the first to test strophomenoid life-mode hypotheses biomechanically. On the basis of flume experiments using models, and correlations between paleoenvironment and morphology, Alexander suggested that geniculation was an ecophenotypic response to high rates of sedimentation, possibly related to storm events. Alexander's hypothesis was further tested (Alexander \& Daley 1994) in Upper Ordovician beds of Ohio. Assuming that storm events and higher sedimentation rates occur closer to shore, the percentage of geniculate specimens was predicted to increase in nearshore environments. This prediction was confirmed; geniculation tended to increase from offshore to nearshore environments through four separate shoaling-upwards cycles.

Subsequent flume work by Alexander (1984) used fossils on a fine sandy substrate. Concavo-convex, strophic 


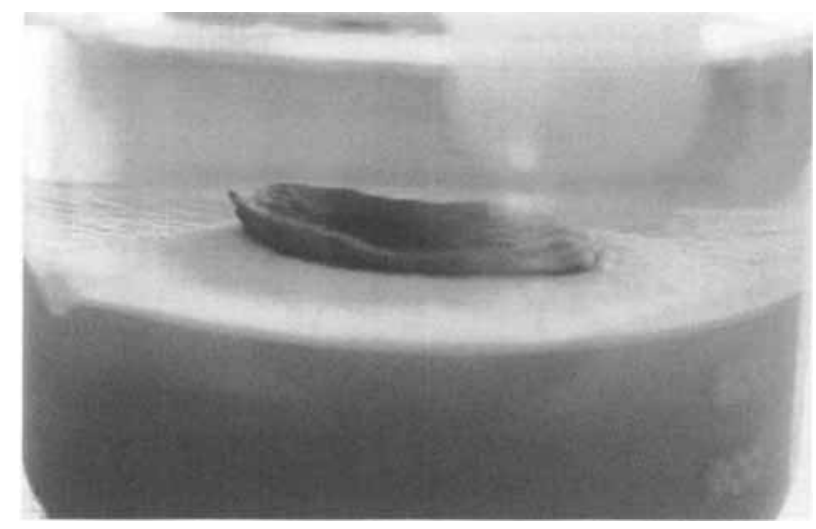

Fig. 2. Semi-infaunal position of Rafinesquina alternata. Specimen is floating in mud ( $50 \%$ salt water by volume), convex-valve down, with commissure above the sediment-water interface. This is an example of Thayer's (1975) iceberg strategy; note that most of the shell is below the sediment. Specimen is geniculate individual shown in Fig. $1 \mathrm{H}$.

brachiopods were more hydrodynamically stable than biconvex or non-strophic morphologies of other brachiopods. However, sediment on the upstream side of the concavo-convex brachiopod was consistently scoured away, while sediment tended to bury the downstream margin of the specimen. This scour pattern was observed by Leighton \& Savarese $(1995,1996)$ too, who also noted that flatter specimens generated less scour and downstream burial at any given current velocity, suggesting that flatter individuals would be less susceptible to burial of the commissure in currents.

Savarese (1994) utilized models of several concavoconvex brachiopods in a flume to determine the flowinduced forces affecting morphologies. He observed that geniculate specimens experienced greater drag, and he concluded that this morphology would be more susceptible to transport and scour than would flatter specimens.

The results of Leighton \& Savarese $(1995,1996)$ and Savarese (1994) suggest that geniculation should decrease in high-energy environments nearshore, presenting an alternative hypothesis to that of Alexander. LaBarbera's (1981) work further supports the hypotheses that a strongly concavo-convex geometry and geniculation were best suited for low energy, soft substrate environments, and that concavo-convex organisms rested convex-valve-down.

Models of Mesozoic plano-convex pteriomorphs oriented convex down 'floated' in modern, shallow marine, fluid-rich, carbonate muds. Similarly, strophomenoids may have floated convex-valve-down in the soft muds (Fig. 2). This is the 'iceberg' strategy described by Thayer (1975). The brachiopod is suspended in the sediment, but most of its mass rests below the sediment-water interface. The plausibility of this strategy was demonstrated by Leighton \& Savarese $(1995,1996)$ through biomechanical experiments. Geniculate, fossil specimens of $R$. alternata 'floated' in carbonate muds that were $50 \%$ water by volume (Fig. 2). In contrast to geniculate brachiopods, flatter individuals would be less likely to experience transport or burial in higher-energy regimes. The flat morphology usually has been interpreted as an adaptation to soft substrates (Rudwick 1970; Thayer 1975; Alexander 1977), because a flat brachiopod distributes its mass over a greater surface area. This is the 'snowshoe' strategy of Thayer (1975). But the biomechanical results of Leighton \& Savarese $(1995,1996)$ suggest that a flat, thin geometry also may have been successful in a high-energy, hard-substrate habitat.

If these hypotheses regarding profile are correct, then the percentage of geniculate individuals within a species should increase in low-energy, muddy environments. Flat individuals should be more common than geniculate ones in higher-energy environments, but also may be present on soft substrates. Such an environmental distribution also would corroborate the hypothesis that concavo-convex brachiopods lived convex-valve-down. In contrast, if concavo-convex brachiopods lived convexvalve-up, as suggested by Lescinsky (1995), then geniculate individuals should be more common than flat individuals in higher energy environments, and absent from soft substrates.

Plan-view morphology of concavo-convex brachiopods is an important feature that has not been studied as extensively as geniculation. Plan-view morphology approximates the area of contact between the organism and the substrate. This is the area over which the mass of the organism is distributed. As such, the geometry of the planar shape may provide important information on the stability and orientation of the organism in soft substrates.

Alexander (1975) analyzed the plan-view morphology of $R$. alternata by determining the ratio of the hinge-line width to the midline width. Alexander referred to this as the alation index, without any implication of the possession of alae. He demonstrated that individuals from stratigraphically higher units had distinctly higher alation indices than individuals from older units, although environment changed repeatedly within the section. Alexander reasoned that alation (sensu Alexander) provided greater stability on soft substrates and also under high energy conditions. He concluded that alation was adaptively selected and was an example of a directed evolutionary trend.

In a study of the modern terebratulide Terebratalia transversa, Thayer (1986) observed that two individuals of the same length but different widths had lophophores of the same size. Consequently, the lophophore did not extend to the lateral margins of transverse individuals. The additional lateral space functioned as a sediment trap. Upon entering the lateral margins, larger sedimen- 
tary (non-food) particles settled out of the main inhalant current and were ejected anteriomedially by mantle currents without ever contacting the lophophore. Consequently, transverse $T$. transvers a were capable of feeding in highly turbid waters and were more abundant in highturbidity environments. The lateral margin of the mantle cavity of transverse concavo-convex brachiopods may have functioned in the same way. Similarly, Grant (1968) speculated that the transverse productidine brachiopod Marginifera may have used the auricular chambers as a sediment trap.

Although terebratulides have a plectolophe, whereas strophomenoids probably had a ptycholophe or schizolophe (Rudwick 1970; Brunton \& Cocks 1996; Leighton \& Savarese 1996), the hypothesis that transverse concavoconvex brachiopods were adapted for high-turbidity environments deserves further research. If this hypothesis is correct, transverse individuals will be more abundant than equidimensional individuals in turbid, frequently disturbed paleoenvironments.

Determining the distribution of geniculation and planar shape relative to environmental factors such as substrate, depth, and disturbance, will provide an independent test of these functional hypotheses. Understanding the functional morphology of Rafinesquina alternata may also increase understanding of other strophomenoid brachiopods and the concavo-convex morphology.

\section{Paleoenvironment}

Upper Ordovician (Richmondian) limestones and mudstones exposed along the Cincinnati Arch in southeastern Indiana (Fig. 3) are highly fossiliferous. During the Late Ordovician, these sediments were deposited on a gently prograding carbonate ramp in a broad, shallow, epicontinental sea that extended from Pennsylvania to Missouri (Gray 1972; Hay 1981; Meyer et al. 1981; Droste \& Shaver 1983). Indiana was approximately $15-25^{\circ}$ south paleolatitude and had a subtropical climate (Meyer et al. 1981; Droste \& Shaver 1983). Mountains of the Taconic Orogeny, $900 \mathrm{~km}$ to the east, shed siliciclastic sediments westward onto the craton (Hay 1981; Tobin 1982).

Lithostratigraphic units in this study are, in stratigraphic order, the Arnheim (Excello of Hay 1981), Waynesville, and Liberty Members of the Dillsboro Formation (Brookville Formation of Hay 1981), and the lower part of the Whitewater Formation (Fig. 4). These units were originally defined on faunal criteria (Caster $e t$ al. 1955) but were subsequently redefined by relative abundance of limestone to mud (Hay 1981). The lower Whitewater is overlain throughout much of the study area by the Saluda Dolomite. The Arnheim is separated from the Waynesville by a flooding surface (Hay 1981) which is interpreted by Holland (1993) as an unconfor-

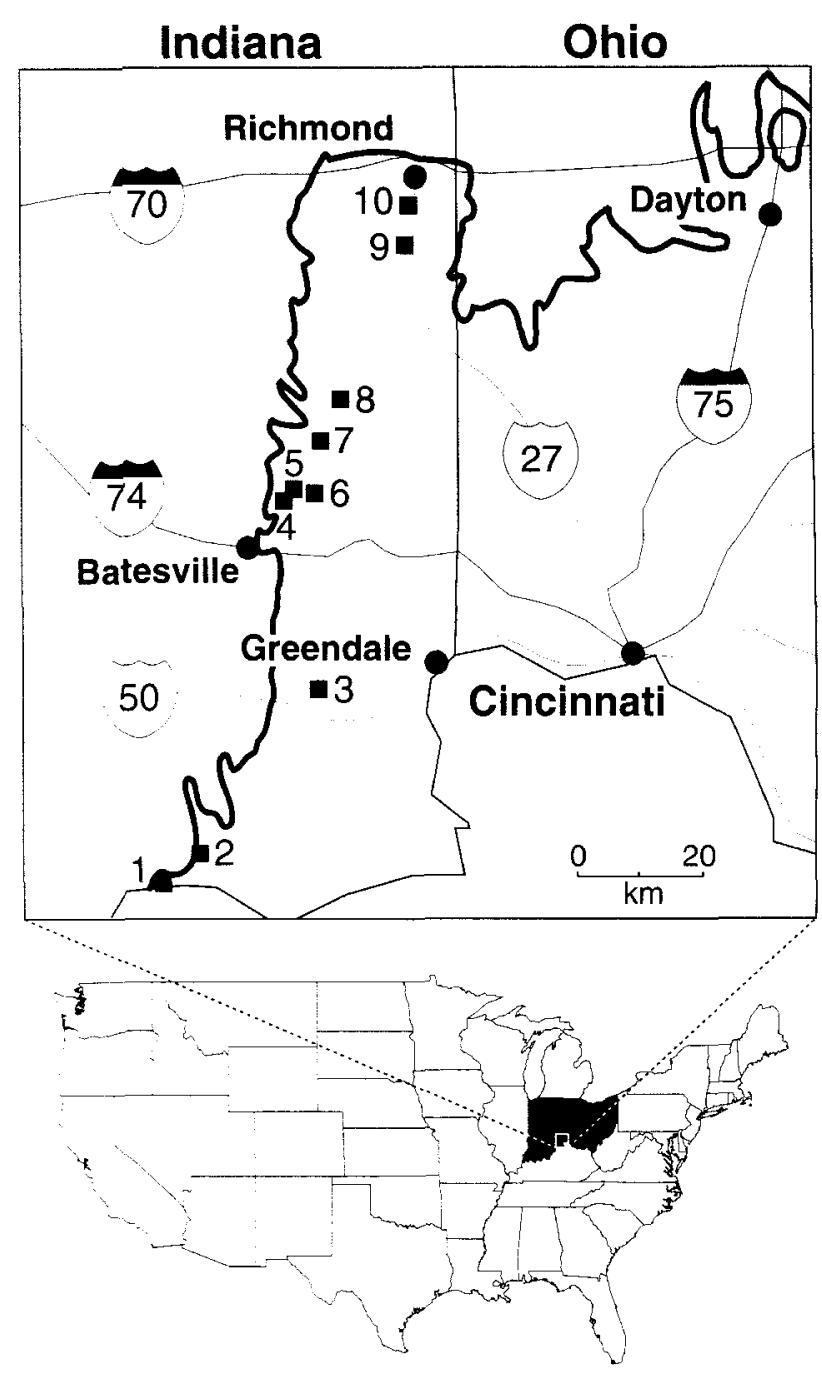

Fig. 3. Map of fossil localities. Dark, wavy line marks the extent of Ordovician outcrop. See Appendix for detailed locality information.

mity. However, most other contacts are gradational. The section varies in thickness geographically, thinning to the south, but is approximately $100 \mathrm{~m}$ thick in the Brookville area (Hay 1981).

The Arnheim to Whitewater section was chosen for several reasons. First, $R$. alternata is the only species of Rafinesquina present within this stratigraphic interval. Therefore, any observed variation cannot be attributed to the presence of multiple species. Second, the section provides an opportunity to sample Rafinesquina populations from several environments. Last, these units, except for the Whitewater, were included in Alexander's (1975) work, but his specimens were collected by bulk sampling over a much thicker stratigraphic interval. This study has finer stratigraphic resolution and larger sample sizes per unit.

Upper Ordovician rocks of the Cincinnati Arch consist of alternating thin beds of limestone and siliciclastic 

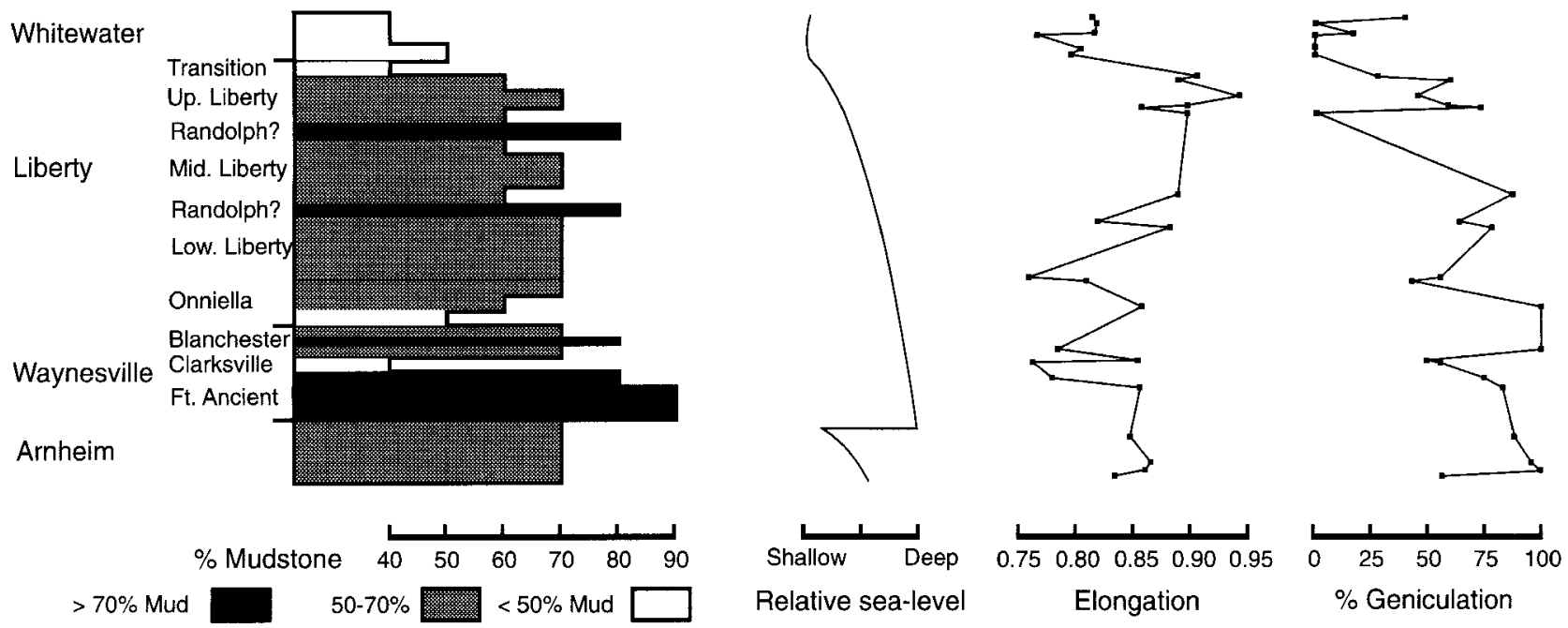

Fig. 4. Relationship between stratigraphy, environmental conditions, and morphology of Rafinesquina alternata.

mudstones. The rocks are virtually flat-lying, having a dip of less than $2^{\circ}$. Limestone and mudstone couplets are usually less than $0.5 \mathrm{~m}$ thick. Numerous explanations for these couplets have been suggested, including oscillating sea level changes (Holland 1993), tectonic pulses from the Taconic Orogeny, carbonate deposition interrupted by storm deposits (Tobin 1982; Lehman \& Pope 1990; Jennette \& Pryor 1993), successional community development (Harris \& Martin 1979), and the interaction of biological carbonate production and subsidence (Leighton 1997).

These couplets are further grouped into larger $(>50 \mathrm{~m})$ sedimentary packages. Within a package, the lime-tomud ratio increases upsection; limestones become thicker while mudstones thin. These packages have been interpreted as shoaling-upwards hemicycles (Fox 1962; Hay 1981; Holland 1993).

The section from the Waynesville to the Whitewater represents one of the shoaling-upwards hemicycles (Fox 1962; Hay 1981) and is equivalent to Holland's (1993) C5 sequence. If this interpretation is correct, the Waynesville represents the deepest water in the Richmondian, 20-30 $\mathrm{m}$ deep, below normal wave base, but probably above storm wave base. The Whitewater represents a higherenergy, shallow, sub- to intertidal environment (Fig. 4). The Arnheim is the uppermost, and presumably most shallow, unit of the previous hemicycle.

The interpretation of these units as shoaling-upwards cycles is based primarily on changes in the relative abundance of limestone to mudstone. Mud-lime abundance is the result of a complex interplay of climate, tectonics, biology, diagenesis, and other factors, and not simply an indicator of depth. However, conodont biofacies analysis corroborates the interpretation of the Waynesville-
Whitewater beds as a shallowing-upwards package (S. Bergström, personal communication, 1997).

Leighton $(1995,1997)$ noted that although limestone abundance increases upsection from the Waynesville to the Whitewater, grainstones are more common in the Waynesville, lowest Liberty (Onniella Zone), and the Whitewater than in the intervening middle and upper Liberty. Richmondian grainstones are commonly wavybedded, and discontinuous or amalgamated in contrast to the thick, tabular, laterally continuous, pack- and wackestones of the Liberty. Furthermore, the grainstones frequently have cross-bedding or rip-up clasts. These features suggest that the grainstones are tempestites.

High tempestite frequency has been used to infer shallow depths (Lehmann \& Pope 1990, Jennette \& Pryor 1993), which would be inconsistent with the hypothesis that the Waynesville was deposited in deep water. However, tempestite frequency may be influenced more by changes in climate patterns than depth, in which case the Waynesville and Whitewater settings may have been more prone to experience storms than the Liberty. The large difference between the Waynesville and the Whitewater in lime-mud ratio may simply be a function of increased storm frequency and erosion during Whitewater time; tempestite beds are sufficiently common in the Whitewater that it is unclear what was normal background deposition. Siltstones form many of the thin beds and drapes between the tempestites; such beds could have been background deposition, but may also have been related to the storms.

The overlying Saluda Dolomite has been interpreted as a shallow, saline lagoon bordered by small reefs (Hay 1981). As the Saluda conformably overlies the Whitewater, all workers (Martin 1977; Oldroyd 1978; Hay 1981; 
Holland 1993; Leighton 1995, 1997) have interpreted the Whitewater as representing a shallow environment, based on its stratigraphic relationship to the shallow Saluda.

In contrast to Waynesville and Whitewater limestones, many Arnheim and Liberty limestones were probably the product of intense biological carbonate production. In Hay's (1981) reconstruction, these units were deposited at intermediate depths. This environment was probably more suitable for organisms than both shallower and deeper waters. Deposition occurred within the photic zone in well-circulated waters, but not so shallow as to be subjected to extremes in energy, turbidity, and salinity.

\section{Methods}

Six-hundred-and-fifty specimens of Rafinesquina alternata were collected at ten localities in southeastern Indiana, USA (Fig. 3). Collecting sites form a zone trending NNE to SSW that roughly parallels depositional strike (Hay 1981). Rafinesquina were collected from 50 individual beds.

Beds with obvious indicators of taphonomic transport, such as cross-bedding, imbrication of fossils, extensive abrasion or fragmentation, preferential orientation of linear elements, etc., were not sampled for brachiopods. Many of these beds have been interpreted as tempestites (Oldroyd 1978; Jennette \& Pryor 1993). As a consequence, grainstones are underrepresented in the samples; most collected beds are packstones, wackestones, or calcareous siltstones. However, this is consistent with the work of Fox (1968) and Martin (1977), who noted that grainstones are less common than pack- and wackestones through much of the section.

Only articulated specimens or disarticulated, but undamaged, pedicle valves were collected and measured. Solitary brachial valves were ignored to avoid possible duplication of data. As demonstrated by Velbel \& Brandt (1989), disarticulation of brachiopod valves is not, alone, evidence of taphonomic transport. The specimens show little evidence of abrasion. Furthermore, except in the case of major storm events, inter-habitat transport was probably rare on epeiric carbonate ramps, because the widths of the environmental facies are typically on a scale of tens of kilometers (Irwin 1965; Read 1985).

For each specimen, length from the center of the hinge line to the center of the commissure, and width, measured along the hinge line, were determined. The pregeniculation and postgeniculation lengths of geniculate individuals were also measured. Pregeniculation length is defined as the line segment from the center of the hinge line to the point of the geniculation. Postgeniculation length is the line segment from the point of geniculation to the center of the commissure. These two line segments are approximately tangent to the pregeniculate and postgeniculate curvature, respectively. All measurements were made to $0.1 \mathrm{~mm}$ and rounded to the nearest millimeter.

The ratio of length to width, hereafter referred to as the elongation index, was calculated for each specimen. Elongate specimens have an elongation index greater than one, and transverse specimens have an elongation index less than one. The elongation index is an approximation of the planar shape of the organism, which is the maximum possible cross-sectional area of the brachiopod in contact with the substrate. The elongation index could be calculated by using the sum of the pre- and postgeniculation lengths, instead of length. This method might approximate growth better but does not describe the planar shape. Note that planar shape is independent of shell curvature; i.e. two brachiopods with different convexities may have identical planar shapes.

Specimens with an obvious and abrupt change in the direction of growth were identified qualitatively as geniculate, regardless of height or convexity. All other specimens were recorded as arcuate.

For each sampled bed, the mean elongation index and the percentage of geniculate individuals were calculated. Unlike the elongation data, geniculation of an individual is a discrete measure; geniculation is either present or absent. Therefore, the percentage of geniculate individuals was calculated for each bed, rather than as a mean.

Morphological variation may be due to the following factors: (1) The natural range of phenotypic variation present in a given population; (2) a directed evolutionary trend in which the population changes in a consistent direction in morphospace over an interval of time; (3) differences in the age distribution of sampled populations if the organism grows allometrically; or (4) phenotypic plasticity or clinal variation in response to (a) the physical environment, or (b) biological influences, such as a character displacement due to interspecific competition. The influences of time (directed evolutionary trend), age distribution, physical environment, and competition on variation in elongation index and geniculation percentage were determined by linear regression analysis. In addition, the effect of geniculation on elongation and vice versa were also included in the analysis to account for the possibility that the two morphological features might be genetically or structurally linked.

A simple linear regression was calculated individually for each of the independent variables. Multiple linear regressions, using all appropriate independent variables, also were performed. If more than one independent variable significantly $(p<0.05)$ influenced morphological variation, then a partial regression was done to determine the effect of any one independent variable without the influence of the other significant variables. A partial regression is a simple regression of a given variable using the residuals from a previous regression on the other independent variables. 
In the regression analyses, time was estimated by relative stratigraphic position of the bed within the section. If the regression reveals that time accounts for a significant percentage of variation in morphology, then the data are consistent with the hypothesis of a directed evolutionary trend.

The influence of ontogeny on morphology may be determined by analysis of morphological variation with respect to age. Timms \& Brunton (1990), in an analysis of growth rates, suggested that geniculation was triggered by the onset of sexual maturity in the productidines Antiquatonia and Plicatifera. If this also were true for Rafinesquina, then regression analysis should demonstrate a correlation between ontogeny and morphology. Unfortunately, age cannot be measured directly in fossil brachiopods, so proxies were used in this study. For the regression on geniculation percentage, the age at geniculation was estimated by mean pregeniculation length of the specimens within a bed. For arcuate specimens, pregeniculation length is equal to anterior-posterior length.

Mean anterior-posterior length served as a proxy for age for all specimens in the regression on elongation index. Length is commonly used to approximate brachiopod age (Rudwick 1970). However, length may not be a reliable indicator of age, particularly for geniculate specimens, because anterior-posterior length never parallels the changing direction of accretionary growth during ontogeny. Therefore, age of geniculate individuals also was estimated by adding the pregeniculation and postgeniculation lengths. As these two measures are roughly tangent to the pregeniculation and postgeniculation curvature, they may better approximate age. The regression was then recalculated separately using this new estimate.

The regression of age on morphology may not adequately reflect ontogenetic variation if growth is determinate. Therefore, small $(<3.2 \mathrm{~cm}$ in length) specimens were culled from the data set and the regression recalculated using only 'adult' (with no implication of sexual maturity) individuals. The length of $3.2 \mathrm{~cm}$ was chosen as the division between adults and non-adults, because approximately one-third of the total sample is smaller than $3.2 \mathrm{~cm}$. Studies on modern brachiopods (Williams \& Rowell 1965) indicate that most species achieve maturity at approximately one-third to one-half of average adult size.

Two separate environmental factors, mudstone percentage and grainstone percentage (both calculated relative to total lithology), were analyzed in the regression analyses. Note that as mudstone percentage increases, limestone percentage must decrease, and vice versa, but that grainstone percentage may not be affected.

Because lithology within the Richmondian is a function of numerous factors (rate of terrigenous input, rate of biological production of carbonate, water energy, subsidence, depth, and storm activity), the composition of a sin- gle bed may not be representative of the background depositional environment. For example, a bed may be deposited by a single, sudden, storm event. To account for this possibility, the background environment of each collection bed was estimated by calculating a weighted average of lime-mud abundance within the 4-m interval enveloping the bed. Beds were identified every $0.25 \mathrm{~m}$ within the 4-m interval, and mudstones and limestones were assigned a value of 0 or 1 , respectively. Beds closer to the center of a given interval contribute more to the average than do beds farther away from the center. The average is calculated as follows:

$$
\left.X=\left(\sum \text { value }^{\star} 1 / D\right)\right) /\left(\sum(1 / D)\right)
$$

where $\mathrm{D}$ is the distance in meters from the center of the interval. For example, a bed $0.25 \mathrm{~m}$ from the center has a $1 / D=4$. A bed $2 \mathrm{~m}$ from the center has a $1 / D$ of 0.5 . The $1 /$ $D$ of the collection bed $(D=0)$, the centralmost bed, was arbitrarily set at 8 , twice the $1 / D$ of a bed $0.25 \mathrm{~m}$ from the center. This method smoothes small-scale variations within the data (Hay 1981). Further description of the method is provided in Leighton (1995). The resulting 'average' lime-mud abundance is used in the regression as a proxy for background substrate conditions experienced by the organism.

Although grainstones were collected less so as to avoid problems of taphonomic interpretation, the frequency of grainstone occurrence may reflect the degree of disturbance and turbidity within the environment (Brett et al. 1990). Grainstones within the study were highly correlated with wavy (as opposed to tabular) bedding, discontinuous and amalgamated units, cross-bedding, shell imbrication, and rip-up clasts (Leighton 1995, 1997), all of which suggest tempestite deposition (Jennette \& Pryor 1993). Moreover, grainstone-rich intervals consistently contained greater quantities of detrital quartz silt than grainstone-poor intervals (Leighton 1995, 1997), which also is indicative of turbid conditions. Therefore, grainstone percentage was calculated, using the weighted-average method described above. The grainstone percentage was then used as a proxy for environmental disturbance and turbidity in the regression analyses.

Interspecific competition was estimated by calculating the ratio of the number of Strophomena planumbona to Rafinesquina alternata within each collection bed. $S$. planumbona is the most probable competitor of $R$. alternata. The two species are closely related (Pope 1976), have similar body plans (Fig. 1A), and are inferred to have had a similar semi-infaunal life mode (Richards 1972). Both lived free-lying on the substrate. Unlike Rafinesquina, $S$. planumbona has a convex brachial valve and a concave pedicle valve and is smaller and usually more transverse. $S$. planumbona is common throughout the middle and upper Liberty and rare in lower Liberty and Whitewater beds. S. planumbona was absent from all other collected beds, and so these beds have a S. planumbona:R. alternata 
ratio of zero. The ratios were used as independent variables in the regression analyses.

Rafinesquina that experienced competition from $S$. planumbona would have benefited from a character displacement. If this hypothesis is correct, the resulting Rafinesquina phenotype would be less similar to the average phenotype of $S$. planumbona. In contrast, $R$. alternata living in the absence of $S$. planumbona would have been less affected by interspecific competition, and so no character displacement would have occurred. S. planumbona is not geniculate and virtually always more transverse than $R$. alternata. Therefore, $R$. alternata found in association with $S$. planumbona should be less transverse or more likely to be geniculate than $R$. alternata from beds dominated by Rafinesquina.

McNaughton \& Wolf (1970) suggested that a numerically dominant organism experiences greater intraspecific than interspecific competition, and so manifests increased morphological variability in order to niche differentiate within the species. In contrast, an organism that is less abundant relative to other species will experience greater interspecific competition and so will be more uniform in shape. This hypothesis was supported by Alexander (1976) using Paleozoic and Mesozoic rhynchonellides. If the morphology of $R$. alternata is influenced by competition, populations of $R$. alternata living with $S$. planumbona should be morphologically less variable (lower standard deviation) than populations of $R$. alternata living alone.

Rafinesquina is also found in association with Leptaena richmondensis and with Strophomena vestusa. However, these associations were too uncommon to be statistically significant, and so were not included in the study.

The possibilities that geniculation and elongation are linked genetically, constrain one another structurally, or are functionally related, were tested by using geniculation percentage as an independent variable in the regression on elongation and vice versa. Admittedly, elongation or geniculation might be influenced by features other than each other, but these two features account for much of the geometry of Rafinesquina.

\section{Results}

Results of the single and multiple linear regressions are summarized in Table 1. Single regression analysis indicates that only two independent variables, the grainstone percentage and the Strophomena-Rafinesquina ratio (S-R ratio), each account for more than $10 \%$ of variation of planar shape $(p<0.01$ for both variables). The grainstone percentage, which serves as a proxy for environmental disturbance and turbidity, accounts for $24.9 \%$ of the variation (Table 1, Fig. 5). The S-R ratio, which approximates interspecific competition, contributes to $22.1 \%$ of the
Table 1. Summary of regression results.

Elongation

Single regression results:

\begin{tabular}{lcll}
\hline Variable & Variation & $p$-value & Correlation \\
\hline Stratigraphy & $2.1 \%$ & 0.314 & Negative \\
Geniculation & $4.8 \%$ & 0.128 & Positive \\
Mudstone percentage & $9.6 \%$ & 0.029 & Positive \\
Grainstone percentage & $24.9 \%$ & 0.000 & Negative \\
S-R Ratio & $22.1 \%$ & 0.001 & Positive \\
Length & $0.0 \%$ & 0.997 & Negative \\
Adj. Length & $0.0 \%$ & 0.995 & Negative
\end{tabular}

Adjusted Length $=$ pregeniculation + postgeniculation lengths.

Multiple regression results:

Variation contributed by all variables $=41.7 \%(p=0.000)$

Combined influence of grainstone percentage $+\mathrm{S}-\mathrm{R}$ Ratio $=38.3 \%$

Partial regression results:

$S-R$ Ratio with grainstone percentage removed $=16.9 \%(p=0.003)$

Grainstone percentage with S-R Ratio removed $=19.8 \%(p=0.001)$

Geniculation

Single regression results:

\begin{tabular}{lccl}
\hline Variable & Variation & $p$-value & Correlation \\
\hline Stratigraphy & $36.0 \%$ & 0.000 & Negative \\
Elongation & $4.8 \%$ & 0.128 & Positive \\
Mudstone percentage & $31.0 \%$ & 0.000 & Positive \\
Grainstone percentage & $7.6 \%$ & 0.052 & Negative \\
S-R Ratio & $2.1 \%$ & 0.312 & Negative \\
Pregeniculation & $6.0 \%$ & 0.087 & Negative
\end{tabular}

Multiple regression results:

Variation contributed by all variables $=54.5 \%(p=0.000)$

Combined influence of stratigraphy + limestone percentage $=43.6 \%$

Partial regression results:

Limestone percentage with stratigraphy removed $=8.3 \%(p=0.043)$

Stratigraphy with limestone percentage removed $=12.8 \%(p=0.011)$

variation. Individual $R$. alternata become more transverse (lower mean elongation index) with increasing grainstone percentage and decreasing $\mathrm{S}-\mathrm{R}$ ratio. In contrast, the equidimensional morphotype of $R$. alternata is more abundant in the presence of $S$. planumbona, or in grainstone-poor intervals (Figs. 4, 6).

Multiple regression analysis, using six independent variables, produces similar results (Table 1). The six variables together account for $41.7 \%$ of the variation $(p<0.0005)$, and grainstone percentage and S-R ratio together contribute to $38.32 \%$ of total variation. These results are not affected significantly by substituting the adjusted length (pregeniculation plus postgeniculation length) for length, or by using only 'adult' (length $>3.2$ $\mathrm{cm}$ ) specimens in the analysis.

Among Rafinesquina-bearing rocks, Strophomena planumbona is only present in the Liberty $(S-R$ ratio $>0)$. 
Grainstone percentage is low in the Liberty, suggesting that $S-R$ ratio and grainstone percentage may be linked. Therefore, separate partial regressions of $S-R$ ratio and grainstone percentage were performed to determine their influences on elongation independent of each other. Single linear regressions determine the extent to which an independent variable contributes to variation when all other independent variables are held constant. Partial regression determines the amount of variation due to an independent variable after the effects of other variables have been removed.

A partial regression of the S-R ratio using the residual error from the single regression of grainstone percentage on elongation indicates that the S-R ratio contributes to $16.9 \%$ of variation $(p=0.003)$. This value is the amount of variation attributable to the $S-R$ ratio after the variation due to grainstone percentage has been removed from the

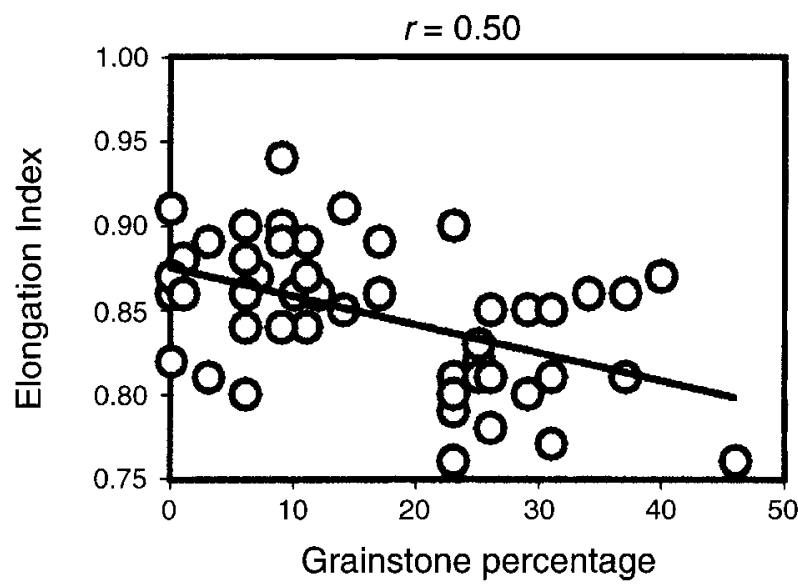

Fig. 5. Scatter-plot and regression line of Mean Elongation Index vs. Grainstone percentage for the 50 Rafinesquina-bearing beds in this study.

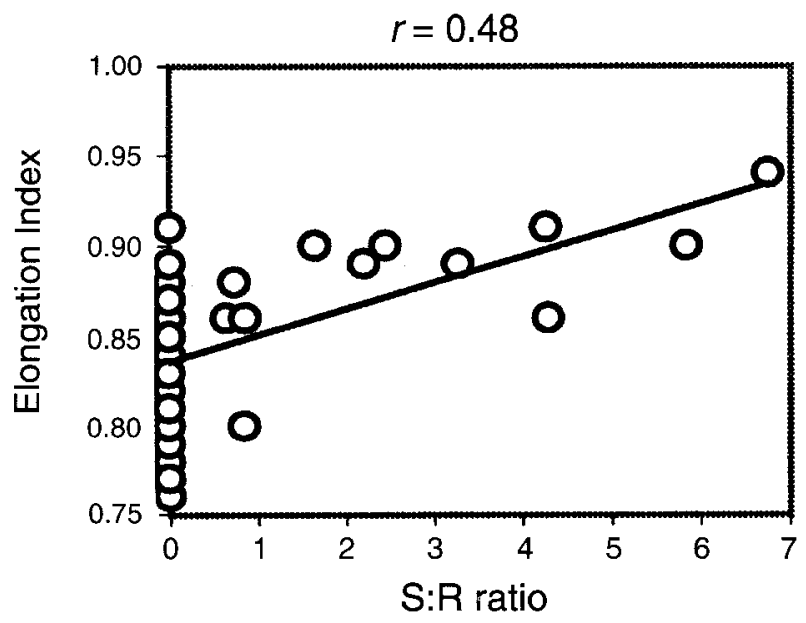

Fig. 6. Scatter-plot and regression line of Mean Elongation Index $v$ s. Strophomena-Rafinesquina ratio for the 50 beds in this study.

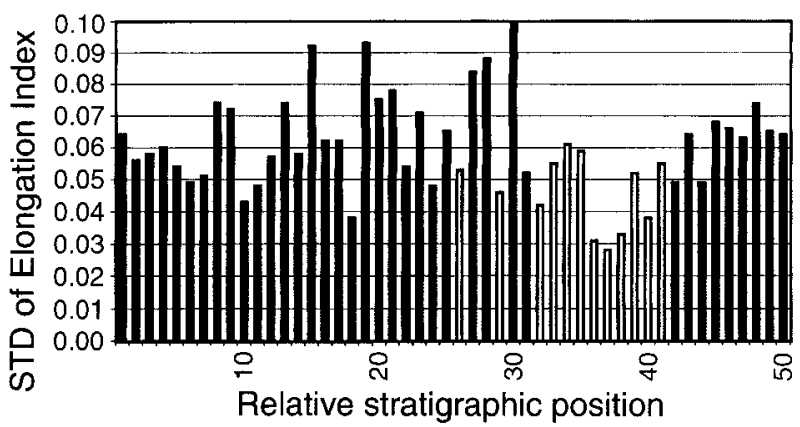

Fig. 7. Standard deviation of Mean Elongation Index of Rafinesquina alternata for the 50 beds. White bars indicate beds in which Strophomena planumbona is abundant. Black bars indicate beds in which S. planumbona is absent or rare (Rafinesquina dominant). Note that the STD generally is lower for Rafinesquina in Strophomena-dominant beds.

analysis. Similarly, a partial regression of grainstone percentage reveals that the grainstone percentage accounts for $19.8 \%$ of the variation $(p=0.001)$ after the effects of the $S-R$ ratio have been removed. These results suggest that not only do the grainstone percentage and S-R ratio contribute significantly to variation in elongation of $R$. alternata, but that their influences on variation are probably independent of each other.

Other statistical tests were performed to examine further the relationship between planar shape, the S-R ratio, and grainstone percentage. Rafinesquina associated with Strophomena planumbona are more equidimensional than Rafinesquina in the absence of S. planumbona (twoway $t$-test, $p<0.0005$ ). The null hypothesis, that there is no significant difference in elongation between Rafinesquina populations from the two different brachiopod associations, is rejected strongly. S. planumbona is almost always more transverse (mean elongation index of 0.738 ) than $R$. alternata (0.849). The more equidimensional population of Rafinesquina (elongation index $=0.891$ ) associated with Strophomena is less similar to Strophomena than is the Rafinesquina population living alone (elongation index $=0.838$ ). This suggests that $R$. alternata may have experienced a character displacement in response to competition from $S$. planumbona.

Variability in Rafinesquina alternata responded in the manner predicted by McNaughton \& Wolf (1970). $R$. alternata from Rafinesquina-dominant beds have a slightly larger standard deviation (0.0741) for elongation than $R$. alternata from beds with Strophomena planumbona present (0.0683) (Fig. 7).

An ANOVA of elongation in response to lithostratigraphic unit indicates that Rafinesquina from the grainstone-poor Arnheim and Liberty samples are distinctly more equidimensional (elongation indices $=0.862$ and 0.869 , respectively) than individuals from the Waynesville (elongation index $=0.826$ ) and Whitewater (elongation 


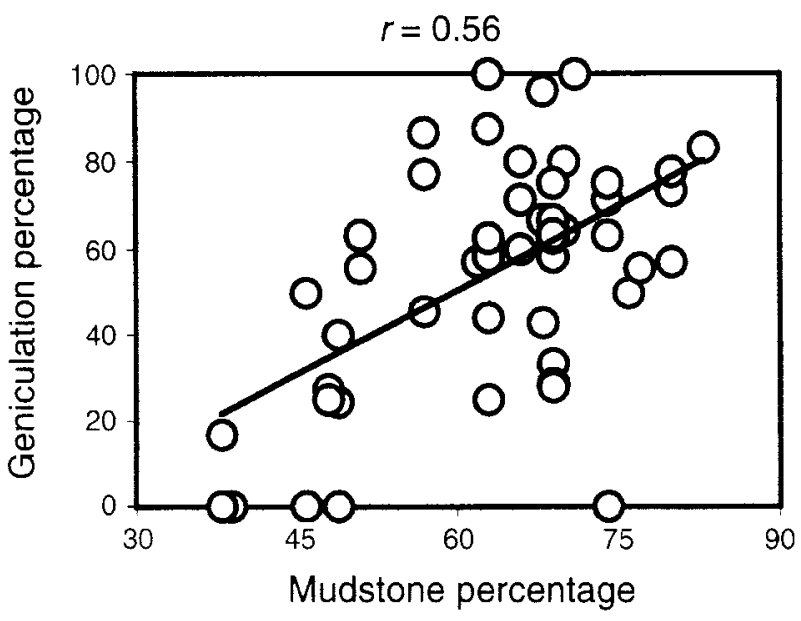

Fig. 8. Scatter-plot and regression line of geniculation percentage v's. mudstone percentage for the 50 beds in the study.

index $=0.811$ ) units. The difference in elongation indices between the above units is significant at the $99 \%$ level of confidence. Middle and upper Liberty individuals are still more equidimensional than specimens from any other interval (elongation index $=0.891$ ). The change in elongation index between the most equidimensional population (upper Liberty) and the most transverse population (Whitewater) is almost 10\%. The relationship between grainstone percentage and planar shape is particularly evident because the elongation index oscillates strongly through time (Fig. 4).

In the case of geniculation, two different independent variables account for a significant percentage of the variation. Stratigraphic position (proxy for time) and mudstone percentage (indicative of substrate) account for $36.0 \%$ and $31.0 \%$, respectively, of the variation $(p<0.0005$ for both variables). The percentage of geniculate individuals decreases through time and with decreasing mudstone percentage (Fig. 4, Fig. 8).

Again, multiple regression analyses are consistent with the above results. The same independent variables that contribute significantly to variation under single regression also account for the most variation under a multiple regression. Stratigraphic position and mudstone percentage account for $43.6 \%$ of the variation in geniculation.

As is evident from Fig. 4, mudstone percentage decreases with increasing stratigraphic position, suggesting that the two parameters may not be independent of each other. Given these results, partial regressions were performed on both mudstone percentage and stratigraphic position, to determine the effect of each independent variable on geniculation. Stratigraphic position accounts for $12.8 \%$ of the variation $(p=0.011)$ after the influence of mudstone percentage had been removed, while mudstone percentage accounts for $8.3 \%$ of the vari- ation $(p=0.043)$ after eliminating the effect of stratigraphic position. While both of these results are statistically significant, the amount of variation produced by either variable independent of the other is relatively small.

Geniculation percentages for each unit also were determined and analyzed. The geniculation percentage for all specimens in the Whitewater, the only unit in which limestone comprises more than $50 \%$ of the rock, is $16.5 \%$. The muddier and stratigraphically lower units, the Arnheim, Waynesville, and Liberty, have geniculation percentages of $69.7 \%, 66.4 \%$, and $50.4 \%$, respectively. The difference in geniculation percentage between the Whitewater and other units is significant at the $99 \%$ level of confidence (one-way ANOVA). The statistical results do not resolve completely the independent influences of substrate and time on geniculation. The null hypothesis, that there is no significant difference in geniculation percentage through time, is strongly rejected.

Pregeniculation length contributes $6.0 \%(p=0.087)$ of the variation in geniculation when tested by single regression. However, the correlation between pregeniculation length and geniculation is negative, i.e. the mean length of arcuate specimens $(3.22 \mathrm{~cm})$ is greater than the mean pregeniculation length $(2.66 \mathrm{~cm})$ of geniculate specimens $(t-$ test, $p<0.0005)$. Arcuate individuals were sufficiently mature to geniculate, but did not.

\section{Discussion}

The hypothesis that planar shape variation in Rafinesquima alternata is controlled primarily by environment cannot be rejected by any of the performed statistical tests. Planar shape variation may be an example of phenotypic plasticity, possibly including a character displacement, or alternatively, morphology may vary along an environmental gradient. These are the only hypotheses consistent with the data. Both hypotheses have strong functional implications. In contrast, hypotheses suggesting that elongation was controlled by non-functional factors, such as age distribution or structural constraints, are rejected statistically.

The regression analyses are consistent with the hypothesis that variation in the planar shape of Rafinesquina alternata is influenced primarily by the environment, including both physical (environmental disturbance and turbidity) and biological (interspecific competition) factors.

Results are not as conclusive for geniculation, but the data are most consistent with the hypotheses of directed evolution and of morphological response to physical environment. The regression results suggest that geniculation of $R$. alternata either varies with time, suggesting a directed evolutionary trend, or varies with substrate con- 
ditions. As in the case of elongation, the accepted hypotheses support a functional interpretation for geniculation.

There is no evidence to support the hypothesis that variation in geniculation is a consequence of population age structure. Recognition of ontogenetic effects on geniculation is problematic. Geniculation is defined by a sharp change in the direction of growth. Therefore, by definition, geniculation, when it occurs, is ontogenetic. The issue is whether or not geniculation will occur in all individuals given a sufficient life span.

As the correlation between pregeniculation length and geniculation is negative, arcuate individuals were sufficiently mature to geniculate, yet did not, demonstrating that morphology was controlled by a factor other than ontogeny. However, this conclusion is predicated on the assumption that growth rates were similar for different morphotypes. Also, as stated previously, results of the regression analyses were not affected significantly when the data were culled to include only 'adults', providing further evidence that differences in population age structure were not a significant control over geniculation percentages.

Previous work by Alexander (1975) and Alexander \& Daley (1994) has demonstrated that over a longer interval of time (the entire Cincinnatian) the geniculation percentage oscillates strongly. Oscillation was not apparent in this study, because the stratigraphic interval was not of sufficient duration. If results from Alexander (1975) are integrated with results from the present study, then the evidence is inconsistent with the directed evolution hypothesis. Therefore, a response to physical environment, specifically substrate type, is the most plausible explanation for the presence or absence of geniculation. In addition, specimens of $R$. alternata are sometimes observed to resupinate subsequent to geniculation, i.e. the growth direction abruptly changes back to the prior growth direction. Resupinate individuals may have experienced multiple environmental fluctuations, and responded accordingly.

The results of this study suggest that each morphotype of Rafinesquina alternata functioned best under a particular set of environmental conditions. If this hypothesis is correct, the paleoenvironmental reconstruction is of special importance, because functional inferences should be consistent with environmental distribution. Paleoenvironmental data thereby constrain functional hypotheses.

A comparison of background versus event deposition in these units is informative (Table 2). Rafinesquina-bearing limestones of the Waynesville and Whitewater are more micritic, and also contain more detrital quartz silt, than Rafinesquina-bearing limestones of the Liberty. Similarly, muds of the Waynesville, and particularly the Whitewater, are generally siltier than Liberty muds. This suggests that the background environment of the Waynesville and Whitewater was more influenced by
Table 2. Summary of the relationships between lithostratigraphic units, environment, and morphology of Rafinesquina alternata.

\begin{tabular}{|c|c|c|c|}
\hline & $\begin{array}{l}\text { Low disturbance } \\
\text { Grainstones rare, } \\
\text { Quartz silt absent }\end{array}$ & $\begin{array}{l}\text { High disturbance } \\
\text { Grainstones common, } \\
\text { Quartz silt present }\end{array}$ & \\
\hline $\begin{array}{l}\text { Formation } \\
\text { Planar shape } \\
\text { Profile }\end{array}$ & Not represented & $\begin{array}{l}\text { Whitewater } \\
\text { Transverse morph. } \\
\text { Arcuate morph. }\end{array}$ & $\begin{array}{l}\text { Coarse substr. } \\
\text { Lime }>\text { mud }\end{array}$ \\
\hline $\begin{array}{l}\text { Formation } \\
\text { Planar shape } \\
\text { Profile }\end{array}$ & $\begin{array}{l}\text { Liberty, Arnheim } \\
\text { Elongate morph. } \\
\text { Geniculate morph. }\end{array}$ & $\begin{array}{l}\text { Waynesville } \\
\text { Transverse morph. } \\
\text { Geniculate morph. }\end{array}$ & $\begin{array}{l}\text { Fine substr. } \\
\text { Mud > lime }\end{array}$ \\
\hline
\end{tabular}

siliciclastics than that of the Liberty. When all limestones, not just those containing Rafinesquina, are examined, the pattern is interesting. Grainstones, which are inferred to be tempestites, are more common in the Waynesville and Whitewater than in the Arnheim and the Liberty (Leighton 1995, 1997). Although the background environment of the Waynesville and Whitewater may have contained silts and muds, disturbances may have been more frequent. Grainstone percentages imply that Rafinesquina in the Waynesville and the Whitewater were probably living in a more frequently disturbed and more turbid environment than their Arnheim and Liberty counterparts. Frequent disturbance is consistent with the shallow environment of the Whitewater. As described above, the Waynesville environment probably was deeper, but it was above storm wave base. Muddy environments such as the Waynesville are often inferred to be low-energy zones with minimal disturbance, but modern marine soft bottoms are easily and frequently resuspended by physical and biological factors (Thistle 1981). If the grainstones in the Waynesville are tempestites, storm activity would be an additional cause of resuspension and turbidity.

Rafinesquina that lived in environments more prone to disturbance are more transverse than Rafinesquina from grainstone-poor intervals (Fig. 6). Substrates formed under conditions of frequent resuspension will be fluidrich. A transverse geometry may have served to distribute the shell mass more evenly in these soft sediments. Alternatively, the lateral mantle cavity of transverse individuals may have functioned as sediment traps, as suggested above. If so, transverse $R$. alternata could continue to feed in water too turbid for other brachiopods. One difficulty with this conclusion is that Strophomena planumbona, rare or absent in the muddier Waynesville, is more transverse than $R$. alternata. But $S$. planumbona may have been excluded from these environments for other reasons (see below). These functional hypotheses are testable biomechanically and should be the subject of future work.

The regression analyses are consistent with the hypothesis that variation in the elongation of Rafinesquina is a 
character displacement. The narrower variation (smaller standard deviation) in elongation of $R$. alternata from $S$. planumbona-dominated beds, compared with $R$. alternato from Rafinesquina-dominated beds, supports this interpretation. As such, this study documents an example of morphological variation in fossil brachiopods responding to interspecific competition, similar to Alexander's (1976) work on rhynchonellides. It could be argued that this is a weak example, as the Rafinesquina-Strophomena association is confined primarily to one interval. However, the interval is almost $20 \mathrm{~m}$ thick in most sections, included multiple sampled beds, and encompasses the entire stratigraphic range of $S$. planumbona in the region. Moreover, $R$. alternata both below and above the interval are more transverse than $R$. alternata within the interval.

The zone dominated by Strophomena planumbona is approximately equivalent to the middle and upper Liberty. Because Rafinesquina alternata from this interval are less transverse, the strong statistical results in support of the competitive hypothesis may be a statistical artifact of the environmental hypothesis, but the partial regression results described above suggest otherwise.

However, responses to physical environment and to competition are not mutually exclusive, as demonstrated in the studies of Connell (1961) on barnacles and Fenchel (1975) on mud snails. A weak competitor, possibly a generalist, may develop a character displacement in order to niche-differentiate from a superior competitor specialized for a given environment. As a specialist, the superior competitor has a narrow environmental tolerance and so is excluded from other environments still available to the generalist. In these harsher environments, the generalist reverts to a 'normal' morphology. The stronger competitor need not manifest a character displacement (Connell 1961).

In this study, Rafinesquina alternata is inferred to be the competitively weak generalist, and Strophomena planumbona is the competitively strong specialist. $R$. alternata is frequently present in beds that lack $S$. planumbona, but $S$. planumbona rarely is found without $R$. alternata. $S$. planumbona is present in the middle and upper Liberty, and rarely in the lower Whitewater. The stratigraphic and environmental distributions of $R$. alternata and $S$. planumbona in this study are consistent with those reported by Fox (1968) for different localities in southeastern Indiana.

The relatively narrow range of S. planumbona may be a function of limited morphological variability. S. planumbona is never geniculate and displays minimal variation of plan-view morphology (standard deviation of elongation $=0.065$ ). In contrast, $R$. alternata (standard deviation of elongation $=0.267$ ) is present, and often abundant, through most of the Richmondian rocks of southeastern Indiana. It is found in the lower Waynesville (Ft. Ancient) and also, though rarely, in the silty transition zone between the Liberty and the Whitewater. Both of these intervals have been interpreted as low-diversity, possibly restricted environments (Oldroyd 1978; Hay 1981; Leighton 1995). Interestingly, the only interval lacking Rafinesquina is a very high-diversity zone in the middle Liberty, implying that $R$. alternata may have been competitively excluded. Other species of Rafinesquina also have a relatively high environmental tolerance (Titus 1993), and Bretsky (1969) noted that Rafinesquina was the only brachiopod commonly found in more than one community in the Upper Ordovician Appalachian Basin.

The presence or absence of geniculation probably is an example of phenotypic plasticity or stabilizing selection within an environment. Geniculate individuals are significantly less common in the limestone and tempestitedominated Whitewater. This result is inconsistent with Lescinsky's (1995) hypothesis that concavo-convex brachiopods lived convex-valve-up. As geniculate Rafinesquina are abundant in mud-rich intervals, they must have lived convex-valve-down. In the convex-up orientation, the commissure would have sunk into the sediment, preventing the animal from feeding.

This study supports the convex-valve-down paradigm and agrees with predictions based upon the work of Savarese (1994) and Leighton \& Savarese $(1995,1996) . R$. alternata living in the higher-energy and harder-substrate environment of the Whitewater benefited from a flatter profile, by experiencing less drag and a decreased likelihood of hydrodynamic transport. In contrast, geniculate R. alternata in less disturbed, muddier environments were able to 'float', convex-valve-down, on the soft, muddy substrates.

These data appear to contradict the results of Alexander \& Daley (1994), who suggested that nearshore individuals were more likely to be geniculate. However, Alexander \& Daley's study relied on previous environmental interpretations which assumed that tempestite frequency was the best indicator of depth. Also, Alexander \& Daley did not collect from the Whitewater, and this unit may represent a unique environment within the Cincinnatian. No other Cincinnatian unit is as carbonate-rich as the Whitewater (Hay 1981), and excepting the overlying Saluda Dolomite and possibly the laminated silts of the Liberty-Whitewater transition zone, the Whitewater is the shallowest environment in the Cincinnatian. Whitewater substrates probably were harder than any other Richmondian substrates. In addition, the combination of high storm frequency and shallow, potentially high-energy, conditions would have produced a highly disturbed environment. Although tempestites are common through much of the Cincinnatian section, the Whitewater probably represents the most frequently disturbed environment in this interval.

Vermeij (1987) has argued that although storms may contribute significantly to mortality, such catastrophic 
events may not be a significant selective force of evolution, because of the comparative rarity and randomness of storms in most environments, compared to ongoing biological competition and background environmental conditions. However, Denny (1991, 1994) contends that disturbances such as storms can be a significant factor of selection. Storms may have been sufficiently common during Whitewater time to constitute a major selective force. A flatter, arcuate morphology presents a lower profile to currents, decreasing the risk of transport. Moreover, if the background environment tended to be sandy or silty, rather than muddy, the coarse substrate may have inhibited a semi-infaunal life strategy, further exposing geniculate individuals to risk of entrainment.

Below the Whitewater, the undetermined effects of background sedimentation on morphology may be more significant than the effects of storm sedimentation. Alexander (1975) suggested that geniculation was a response to high sedimentation. However, background sedimentation rates have not been determined for the Cincinnatian. Background sedimentation in Cincinnatian environments was controlled by the interplay of the rate of terrigenous siliciclastic input and the rate of biological carbonate production. Consequently, characterization of an environment as either 'muddy' or 'limy' is insufficient to evaluate the background sedimentation rate. Some quiet, low-energy, infrequently disturbed, muddy environments may have relatively high rates of sedimentation. Moreover, a muddy environment may be more prone to resuspension of sediment, which may pose a greater risk of burial to the organism than would a high sedimentation rate. More work needs to be conducted on the effects of resuspension and of background and storm sedimentation within the Cincinnatian environment in order to further constrain these functional hypotheses.

On the basis of current data, the environmental distribution of Rafinesquina alternata is consistent with the hypothesis that variation in planar shape and geniculation of $R$. alternata was controlled primarily by environmental conditions. Biomechanics (Leighton \& Savarese 1995, 1996), environmental distribution, and the factors controlling morphology all corroborate the functional hypothesis that geniculation enabled concavo-convex brachiopods to live semi-infaunally, convex-down in soft substrates. Moreover, the results argue that flatter concavo-convex brachiopods were not restricted to soft substrates, and actually may have functioned well in a higherenergy environment.

In addition, this study suggests hypotheses explaining the function of planar shape. These hypotheses should be tested biomechanically. For both planar shape and geniculation, all interpretations supported by the data have strong functional implications. Variation in planar shape and geniculation of $R$. alternata is functional, and possibly adaptive.
Acknowledgements. - This research was supported by a grant from the Lerner-Gray Fund for Marine Research, American Museum of Natural History. The author wishes to thank Drs. Richard Alexander, Richard Cowen, and Howard Brunton for their thoughtful reviews, and Drs. Tomasz Baumiller, Alan Horowitz, and Daniel Fisher for their advice and comments. However, the author is solely responsible for the opinions expressed herein. Bonnie Miljour was especially helpful with the figures. Lastly, the author wishes to thank Dr. Michael Saverese, whose patience, thoughtfulness, and advice were instrumental in the development of this research.

\section{References}

Alexander, R.R. 1972: The autecology of the Cincinnatian (Upper Ordovician) brachiopod Rafinesquina: a biometric analysis. Geological Society of America, Abstracts with Programs 4:6, 305-306.

Alexander, R.R. 1975: Phenotypic lability of the brachiopod Rafinesquina alternata (Ordovician) and its correlation with the sedimentologic regime. Journal of Paleontology 49, 607-618.

Alexander, R.R. 1976: Intraspecific variability in rhynchonellid brachiopods: test of a competitive hypothesis. Lethaia 9, 235-244.

Alexander, R.R. 1977: Growth, morphology, and ecology of Paleozoic and Mesozoic opportunistic species of brachiopods from IdahoUtah. Journal of Paleontology 51, 1133-1149.

Alexander, R.R. 1984: Comparative hydrodynamic stability of brachiopod shells on current scoured arenaceous substrates. Lethaia 17, $17-32$.

Alexander, R.R. 1989: Influence of valve geometry, ornamentation, and microstructure on fractures in Late Ordovician brachiopods. Lethaia 22, 133-148.

Alexander, R.R. \& Daley, G.M. 1994: Onshore-offshore patterns of variability in geniculation in the Late Ordovician (Cincinnatian) brachiopod Rafinesquina alternata. Geological Society of America, Northeastern Section, Abstracts with Programs 26:3, 1-2.

Bretsky, P.W. 1969: Central Appalachian Late Ordovician communities. Geological Society of America Bulletin 80, 193-212.

Bretsky, P.W. \& Bretsky, S.S. 1975: Phenetic variation in some middle Ordovician strophomenid brachiopods. Geological Society of America Memoirs 142, 3-36.

Brett, C.E., Miller, K.B. \& Baird, G.C. 1990: A temporal hierarchy of paleoecologic processes within a Middle Devonian epeiric sea. In Miller, W., III (ed.): Paleocommunity Temporal Dynamics: The LongTerm Development of Multispecies Assemblies, 178-209. Paleontological Society Special Publication 5.

Brunton, C.H.C. \& Cocks, L.R.M. 1996: The classification of the brachiopod order Strophomenida. In Copper, P. \& Jin, J. (eds.): Brachiopods. Proceedings of the 3rd International Brachiopod Congress, 47-51. Balkema, Rotterdam.

Caster, K.E., Dalve, E.A. \& Pope, J.K. 1955: Elementary Guide to the Fossils and Strata of the Ordovician in the Vicinity of Cincinnati, Ohio. 47 pp. Cincinnati Museum of Natural History.

Connell, J.H. 1961: The influence of interspecific competition and other factors on the distribution of the barnacle Chthamalus stellatus. Ecology $42,710-723$.

Denny, M.W. 1991: Biology, natural selection and the prediction of maximal wave-induced forces. South African Journal of Marine Sciences 10, 353-363.

Denny, M.W. 1994: Extreme drag forces and the survival of wind-and water-swept organisms. Journal of Experimental Biology 194, 97-115.

Droste, J.B. \& Shaver, R.H. 1983: Atlas of Early and Middle Paleozoic Paleogeography of the Southern Great Lakes Area. 32 pp. State of Indiana Geological Survey, Special Report 32.

Fenchel, T. 1975: Character displacement and coexistence in mud snails (Hydrobiidae). Oecologia 20,19-32. 
Fox, W.T. 1962: Stratigraphy and paleoecology of the Richmond Group in southeastern Indiana. Geological Society of America Bulletin 73 , $621-642$.

Fox, W.T. 1968: Quantitative paleoccologic analysis of fossil communities in the Richmond Group. Journal of Geology 76, 613-640.

Grant, R.E. 1968: Structural adaptation in two Permian brachiopod genera, Salt Range, West Pakistan. Joumal of Paleontology 42, 1-32.

Gray, H.H. 1972: Lithostratigraphy of the Maquoketa Group (Ordovician) in Indiana. Indiana Department of Satural Resources Geological Survey Special Report 7.31 pp.

Harris, F.W. \& Martin, W.D. 1979: Benthic community development in limestone beds of the Waynesville (upper Dillsboro) Formation (Cincinnatian Series, Lpper Ordovician) of southeastern Indiana Journal of Sedimentary Petrology 49, $1295-1305$.

Hay, H.B. 1981: Lithofacies and formations of the Cincinnatian Series (upper Ordovician), southeastern Indiana and southwestern Ohio. Ph.D. dissertation, Miami Liniversity, $236 \mathrm{pp}$.

Holland, S.M. 1993: Sequence stratigraphy of a carbonate-clastic ramp: the Cincinnatian Series (Cpper Ordovician) in its type area. Geologial Society of America Bulletin 105,306-322.

Irwin, M.L. 1965: General theory of epeiric clear water sedimentation. Bulletin of the Anerican Association of Petroleum Geologists 49, 445459.

Jennette, D.C. \& Pryor. W.A. 1993; Cyclic alternation of proximal and distal storm facies: Kope and Fairview Formations (upper Ordovician), Ohio and Kentucky. Journal of Sedimentary petrology 63, $183-$ 203.

LaBarbera, M. 1981: The ecology of Mesozoic Gryphaea, Exogyra, and Iymatogyra (Bivalvia: Mollusca) in a modern ocean. Paleobiology' $510-526$.

Lamont, A. 1934: Lower Paleozoic brachiopods of the Girvan District, with suggestions on morphology in relation to environment. Anmals and Magazine of Katural History, London Series 10:14, 161-184.

l.ehnan, D. \& Pope, J.K. 1990: Lpper Ordovician tempestites from Swatara Gap, Pennsylvania. Palaios 4, 553-564.

[leighton, L.R. 1995: Factors influencing morphological variation in the articulate brachiopod Rafinesquina alternata, Lpper Ordovician (Richmondian |, southeastern Indiana. M.S. thesis, Indiana Lniversity. $96 \mathrm{pp}$.

Leighton, I.R. 1997: Reevaluation of Richmondian anvironments. Geological Society of America, North-Central Section, Abstracts with Programs 29:4, 30-31.

Leighton, L.R. \& Salarese, M. 1995: Envirommental distribution and biomechanics of geniculation in the brachiopod Rafineswina alternata. Geological Society of America, Abstracts with Programs 27:6, 445.

Leighton, L.R. \& Savarese, M. 1996: Functional and taphonomic implications of Ordovician strophomenid brachiopod valve morpholog: In Copper, P. \& Jin, I. (eds.): Brachiopods. Procedings of the 3 rd International Brachopod Congress, 161-168. Balkema, Rotterdan.

Lescinsky, H.L. 1995: The life orientation of concavo-convex brachiopods: overturning the paradigm. Paleobiology 21, 520-551.

Martin, W.D. 1977: Petrology of the Cincinnatian series limestones (upper Ordovician) of Indiana and Ohio. In Pope, J.K. \& Martin. W.D. (eds): Biostratigraphy and Paleoenviromments of the Cincinnatian Series, Southeastern Indiana: Setenth Anmal Field Conference Gindebook, SEPM, Grent Lakes Section 11-1-26.
McNaughton, S.L. \& Wolf, L.L. 1970: Dominance and the niche in ecological systems. Science 167, 131-139.

Never, D.L., Tobin, R.C., Pryor, W.A. et al, 1981: Stratigraphy, sedimentologv, and paleoecology of the Cincinnatian Series (upper Ordovician) in the vicinity of Cincinnati, Ohio. In Roberts, T.G. (ed.): GSA Cincinnati '81, Field Trip Guidebooks 1, 31-71.

[Oldroyd, J.D. 1978: Palcocommunities and environments of the Dillsboro and Saluda formations (upper Ordovician), Madison, Indiana. Ph.D. dissertation, University of Michigan. $329 \mathrm{pp}$.)

Pope, I.K. 1976: Comparative morphology and shell histology of the Ordovician Strophomenacea (Brachiopoda). Palaeontographica Americana 8, 129-213.

Read, J.F. 1985: Carbonate platform facies models. Bulletin of the American Association of Petroleum Geologists 66, 860-878.

Richards, R.P. 1972: Autecology of Richmondian brachiopods (Late Ordovician of Indiana and Ohio). Journal of Paleontology 46, 386405

Rudwick, J.M.S. 1970: Living and Fossil Brachiopods, 199 pp. Hutchinson, London

Savarese, M. 1994: Taphonomic and paleoecological implications of flow-induced forces on concavo-convex articulate brachiopods: an experimental approach. Lethaia 27, 301-312.

Savarese, M. 1995a: Inferring behavior in the fossil record: how are functional plausibility, utility, and adaptation distinguished? Geological Socity of America, North-Central and South-Central Sections 29, 84 .

Savarese, M. 1995b: Functional significance of regular archaeocyathan central cavity diameter: a biomechanical and paleoecological test. Paleoliology 21, 356-378.

Thayer, C.W. 1975: Morphologic adaptations of benthic invertebrates to soft substrata. Joumal of Marine Research 33, 177-189.

Thayer, C.W. 1986: Are brachiopods better than bivalves? Mechanisms of turbidity tolerance and their interaction with feeding in articulates. Paleobiology 12,161-174.

Thistle, D. 1981: Natural physical disturbances and communities of marine soft bottoms. Marine Ecology Progress Series 6, 223-228.

Timms, A.E. \& Brunton, C.H.C. 1990: Growth rates and periodicity in Antiquatonia and Plicatifera, Lower Carboniferous productacean brachiopods. In MacKinnon, D.I., Lee, D.E. \& Campbell, J.D. (eds.): Brachiopods Throtgh Time. Proceedings of the 2 nd International Brachiopod Congress, 41-47. Balkema, Rotterdam.

Titus, R. 1993: Cryptic variation in the Trentonian Rafinesquina lineage. Geological Society of America, Abstracts with Prograns 25:1, 51.

[Tobin, R.C. 1982: A model for cyclic deposition in the Cincinnatian series of southwestern Ohio, northern Kentucky, and southeastern Indiana. Ph.D. dissertation, University of Cincinnati. 483 pp.

Velbel, M.A. \& Brandt, D.S. 1989: Differential preservation of brachiopod valves: Taphonomic bias in Platystrophia ponderosa. Palaios 4 , $193-195$.

Vermeij, G.J. 1987: Evolution and Escalation: An Ecological History of Life. 528 pp. Princeton University Press, Princeton, N.J.

Williams, A. \& Rowell, A.J. 1965: Brachiopod anatomy. In Moore, R.C. (ed.): Treatise on Invertebrate Paleontology, Part H, Brachiopoda I, H6-H56. Geological Society of America, Boulder, Col., and University of Kansas Press, Lawrence, Kansas. 


\section{Appendix}

\section{Fossil localities}

Locality numbers correspond to localities shown in Figure 3.

1. Valley Wall Cut. Middle Arnheim to top of Liberty. Road cuts on north side of Rt. 56, located 2.0-3.0 miles west of the intersection of Rts. 56 and 421 in Madison, Indiana. SW 1/4, Section 33; \& SE 1/4, Section 32, T4N, R10E, Madison West Quadrangle.

2. Madison 421 Cut. Base of Arnheim to top of Liberty. Series of road cuts and adjacent stream bed to east on east side of Rt. 421, located $0.7-$ 3.0 miles north of the intersection of Rts. 56 and 421 in Madison, Indiana. W 1/2, Section 24, T4N, R10E, Canaan Quadrangle; \& NE 1/4 of NE 1/4, Section 35 (incomplete), T4N, R10E, Madison West Quadrangle.

3. Taylor Creek. Middle Waynesville to upper Liberty. Stream beds and associated slope to west of Taylor Creek, north of bridge 1.2 miles east of Weisburg, Indiana. E $1 / 2$ of SE $1 / 4$, Section 31 , T7N, R2W, Sunman Quadrangle.

4. St. Peter. Middle to upper Liberty. Stream beds of the East Fork of Blue Creek, running parallel to, and south of road between towns of St. Peter and Highland Center, located 0.6-1.2 miles east of St. Peter. S 1/2 of SW 1/4, Section 29, T8N, R2W, Spades Quadrangle.

5. East Fork. Middle Waynesville to upper Liberty. Stream beds of the East Fork of Blue Creek and an unnamed tributary to the east. S 1/2, Section 19, and S 1/2, Section 20, T8N, R2W, Spades Quadrangle.
6. South Gate. Upper Arnheim to lower Whitewater. Massive road cut on both sides of Rt. 1, approximately 1.0 miles north of South Gate, Indiana. NW 1/4 of SE 1/4, Section 23, T8N, R2W, Cedar Grove Quadrangle.

7. Bon Well Hill. Upper Arnheim to lower Liberty, Road cut on west side of Rt. 101, and north side of adjoining road to reservoir spillway, approximately 1.8 miles northeast of the intersection of Rts. 101 and 52 in Brookville, Indiana. N 1/2 of SW 1/4, Section 15, T9N, R2W, Whitcomb Quadrangle.

8. Garr Hill. Upper Liberty to lower Whitewater. Road cut on both sides of Rt. 101, north of stream valley, and approximately 5.7 miles northeast of the intersection of Rts. 101 and 52 in Brookville Indiana. NE 1/4 of SE $1 / 4$, Section 35, T10N, R2W, Whitcomb Quadrangle.

9. Richmond 27. Middle Whitewater. Road cut on both sides of Rt. 27, approximately 3.3 miles south of intersection of Rts. 27 and 40 in Richmond, Indiana. SE $1 / 4$ of SW 1/4, Section 17, T13N, R1W, Richmond Quadrangle.

10. Thistlewaite Falls. Upper Liberty to upper Whitewater. Waterfall and streambed of West Fork of Whitewater River, located south of bridge on Falls Rd. in the Spring Grove district of Richmond, Indiana. SW 1/4 of SE 1/4, Section 29, T14N, R1W, Richmond Quadrangle. 